\title{
Attitude of Staff Working in Primary Health Centres with Special Reference to Thoothukudi District
}

\author{
V.Sangeetha, K. Chandra, R. Tiffany, S. Eswaralakshmi, E. Shiney Janet
}

\begin{abstract}
Most health care, services are meant for delivering health services at a rural base within prescribed location of the villages vis-a-vis the health centres. The beneficiaries', opinion on services, an attempt has been made to analyse the data related to the staff at various levels in primary health centres on occupational performance oriented tasks. The study examines the attitude of staff working in most health centres in Thoothukudi District. Both the primary data and secondary data used. Most data collected through interview schedules and secondary data collected through published articles, journals, magazines, books, newspapers, and websites. The data collected from about 300 respondents selected using a random sampling methods covering the villages Alwarthirunagari, Anandhapuram, Arumuganeri, Authur, Boothalapuram, Eppothumvendran, Erachi, Eral, Kadambur, Kalugumalai, Kayathar, Karungulam, Katcherithalavaypuram, Kayamozhi, Keelachekkarakudi, Keelairal, Kulaseharapattinam, Kulathur, Mappilaiyurani, Megnanapuram, Mookkuperi, Mudalur, Mudivaithanendal, Mullakadu, Nagalapuram, Ottanattham, Padukkapathu, Paramankuruchi, Pasuvanthanai, Perilovanpatti, Petmanagar, Pitchivilai, Pudukkottai, Puthiamputhur, Puthur, S. Kailasapuram, Salaiputhur, Sebathiyapuram, Sivakalai, Thenthiruperai, Udaiyarkulam, Vallanadu, Vellalankottai, Veppalodai, Vembar and Villiseri. Statistical Package for Social Science (SPSS) was used to analyze the data. The collected data was analyzed by using appropriate statistical tools like percentage and chi-square test for arriving at conclusions. Finding the study is the hectic pace of life in the world today is taking a great toll on people's body and mind. The villagers', both body and mind feel more at ease only when treated well at centres where they go for treatment.
\end{abstract}

Keywords : Diseases, Patients Behaviour, Primary Health Centres and Village Health Nurse.

\section{INTRODUCTION}

Health is the essence of productive lives. It is integral to

Revised Manuscript Received on December 05, 2019.

* Correspondence Author

Dr.(Smt).V.Sangeetha*, Assistant Professor, PG \& Research Department of Commerce, Sri Sarada College for Women, Tirunelveli, Tamil Nadu, India, (Affiliated to M S University), E-Mail: vsangeetha01@gmail.com

K. Chandra, Assistant Professor, Department of Commerce, A.P.C Mahalaxmi College for Women, Thoothukudi, Tamil Nadu, India, (Affiliated to M S University), E-Mail: chandru66199@gmail.com

Mrs. R. Tiffany., Assistant Professor, Department of Commerce, Holy Cross Home Science College, Thoothukudi, Tamil Nadu, India.

Mrs. S. Eswaralakshmi Part time research scholar of Sri Sarada college for women, tirunelveli) and Assistant professor in M.D. T .Hindu college, tirunelveli

E.Shiney Janet, Principal in Tamil Institute of Science and Management, Vilathikulam. Residing at 3/183,Madurai road, guruvarpatti, vilathiklam, thoothukudi(dt)-628904.

development. The international objective of 'Health for All by 2000, A.D.' was suggested by the World Health Organization. 'Health is brought to reach everyone implies the obstacles to health. The completely take away the malnutrition, disease, drinking water and hygienic food. Most of the developing countries are concerned about the resources of the health sector. Such concerns broadly tell: (I) The sources of finance for health services; (ii) the ability to maintain at least the past funding levels; (iii) Resource allocation patterns and (iv) Economic efficiency and equity in health care delivery. In developed countries too, with rich-economies, the concern about the high cost of health care in the perspective of scarce resources, has called for closer economic seeking and analysis of the health systems prevailing there. In this background, it is important for all public health administrators know and to apply the principles of Economics in health.

\section{OBJECTIVE OF THE STUDY}

1. To analyze the relating to structure of populations profile of the respondents in Thoothukudi District.

2. To understand the infrastructure facilities available in PHCs.

3. To examine the respondents' opinion about the functioning of PHCs and their services.

\section{METHODOLOGY}

Both primary and secondary data used. Most data collected through interview schedules and secondary data collected through published articles, journals, magazines, books, newspapers, and websites. The data collected from about 300 respondents selected using a random sampling methods covering the villages Alwarthitunagari, Anandhapuram, Arumuganeri, Authur, Boothalapuram, Eppothumvendran, Erachi, Eral, Kadambur, Kalugumalai, Kayathar, Karungulam, Katcherithalavaypuram, Kayamozhi, Keelachekkarakudi, Keelairal, Kulaseharapattinam, Kulathur, Mappilaiyurani, Megnanapuram, Mookkuperi, Mudalur, Mudivaithanendal, Mullakadu, Nagalapuram, Ottanattham, Padukkapathu, Paramankuruchi, Pasuvanthanai, Perilovanpatti, Petmanagar, Pitchivilai, Pudukkottai, Puthiamputhur, Puthur, S. Kailasapuram, Salaiputhur, Sebathiyapuram, Sivakalai, Thenthiruperai, 
Udaiyarkulam, Vallanadu, Vellalankottai, Veppalodai, Vembar and Villiseri.

Statistical Package for Social Science (SPSS) was used to analyze the data. The collected data was analyzed by using appropriate statistical tools like percentage and chi-square test for arriving at conclusions.

\section{REVIEW OF LITERATURE}

Satya Sundaram (1990) in his article entitled "the performance of the Indian relating to Economic". On may be divided into the education and health. The quantitative expansion is unaccompanied and any qualitative improvement. In the spheres of health and education, better management of resources should receive top priority

Hamumappa (1998) studied that the efforts of both Central and State government Level to sufficiently meet the social communications desires of the people. The lack of funds to initial social communications like learning, teaching, fitness, strength and power etc

Pant J.C. (2002) in his article entitled "the role of rural women". The economic involvement analyzed the process of rural way of life. The role of women desires to particular awareness to get a notice by rural women.

Rahman Mohammed A. (2006) in his article entitled "measure and explanation the executive effectiveness of private medical clinics". There is considerable inadequacy in the way of private sector. The learning firms that hospital beds, working in specialized doctors, nurses, village health nurse, pharmacy and staff. The compare to additional outpatients, surgical patients and gynaecological patients could be treated.

Perez, (2006) in his article entitled "change the culture of healthcare". The patients will be take care of the health in own manner. The impact of society changed the relationship between patients and their doctors. In generally telephone survey was discovered. Health in order obtained influenced the way they ate, go on the diet and exercised. The health information retrieved from the decision about to treat an illness of the patients.

\section{MATERIALS AND METHODS}

Normally Indians seek medical and health care only when they have a physical problem or illness. Periodic or preventive checkups and tests are not much prevalent. In India, people spend less on health care because of low incomes. This is also partially because of free medical services provided by the government besides due to lack of awareness and level of importance given to their health care.

Table- 1: Structure of the Populations Profile of the Respondents

\begin{tabular}{|c|c|c|}
\hline Populations Profiles & Count & Percentage \\
\hline Gender: & & \\
Man & 81 & 27.0 \\
Woman & 219 & 73.0 \\
\hline
\end{tabular}

\begin{tabular}{|l|c|c|}
\hline Populations Profiles & Count & Percentage \\
\hline Age: & 33 & 11.0 \\
Below 20 & 57 & 19.0 \\
$21-30$ & 82 & 27.3 \\
$31-40$ & 80 & 26.7 \\
$41-50$ & 48 & 16.0 \\
Above 50 & & \\
\hline Designation: & 48 & 16.0 \\
Doctor & 81 & 27.0 \\
Nurse & 49 & 16.3 \\
ANM & 72 & 24.0 \\
VHN & 50 & 16.7 \\
Pharmacist & 288 & 96.0 \\
\hline Marital Status: & 12 & 4.0 \\
Married & & \\
Unmarried & 48 & 16.0 \\
\hline Family Size: & 83 & 27.7 \\
Three & 76 & 25.3 \\
Four & 93 & 31.0 \\
Five & 300 & 100 \\
Above Five & &
\end{tabular}

Table 1 shows that out of 300 respondents, 73 percent of the respondents are female and 27 percent of the respondents are male. About 27.3 percent of the respondents are in the age group of $31-40$ years, 26.7 percent of the respondents are in the age group of 41 - 50 years, 19 percent of the respondents are in the age group of 21 - 30 years, 16 percent of the respondents are in the age group of above 50 years and 11 percent of the respondents are in the age group of below 20 years. While 27 percent of the respondents are designation in doctor, 24 percent of the respondents are designation in VHN (Village Health Nurse), 16.7 percent of the respondents are designation in pharmacist in primary health centres, 16.3 percent of the respondents are designation in ANM (Auxiliary Nurse Midwifery) and 16 percent of the respondents are designation of doctor. About 96 percent of the respondents are married and only 4 percent of the respondents are unmarried. About 31 percent of the respondents are having above five members in their family, 27.7 percent of the respondents are having three members in their family, 25.3 percent of the respondents are having five members in their family and 18.3 percent of the respondents are having below three children in their family.

Table - 2: Reason for Choice

\begin{tabular}{|c|c|c|c|}
\hline S. No & Reason for Choice & Frequency & Percent \\
\hline 1 & Service & 97 & 32.3 \\
\hline 2 & As a Job & 85 & 28.3 \\
\hline 3 & Ambition & 118 & 39.4 \\
\hline & Total & 300 & 100 \\
\hline
\end{tabular}

The PHCs' staff might have selected this medical profession either as a service or as a job or as an ambition sparked at their childhood. 39.4 percent of them were influenced by their fathers, uncles or other doctors who were role models in their childhood or they were inspired and encouraged by them to take up medical profession. 32.3 percent of the respondents selected this as a job since their aptitude and interest in medical studies. With a hard work they entered in to this profession. But about 28.3 percent of the staff wanted to 
serve people to enhance their prestige and make a good career through this profession.

Table - 3: Duration of Service in Rural Areas

\begin{tabular}{|c|l|c|c|}
\hline S. No & \multicolumn{1}{|c|}{ No. of Years } & Frequency & Percent \\
\hline 1 & Up to 3 Years & 52 & 17.3 \\
\hline 2 & $3-6$ Years & 84 & 28.0 \\
\hline 3 & $7-9$ Years & 44 & 14.7 \\
\hline 4 & $10-12$ Years & 58 & 19.3 \\
\hline 5 & $13-15$ Years & 26 & 8.7 \\
\hline 6 & Above 15 Years & 36 & 12.0 \\
\hline & Total & 300 & 100 \\
\hline
\end{tabular}

Source: Primary Data

Table 3 reveals the duration of service of the primary health centres staff and their service in rural areas. 28 percent of them have completed 3-6 years of service in PHCs, 17.3 percent of them have completed up to 3 years of service in PHCs, 14.7 percent of them have completed $7-9$ years of service in PHCs, 12 percent of them have completed above 15 years of service in PHCs and 8.7 percent of them have completed $13-15$ years of service in PHCs.

Table 4: Crowd of Patients

\begin{tabular}{|c|l|c|c|}
\hline S. No & \multicolumn{1}{|c|}{ No. of Years } & Frequency & Percent \\
\hline 1 & Kind service & 174 & 58.0 \\
\hline 2 & Happy to see the patients & 88 & 29.3 \\
\hline 3 & Angry & 7 & 2.3 \\
\hline 4 & Normal & 31 & 10.4 \\
\hline & Total & 300 & 100 \\
\hline
\end{tabular}

Source: Primary Data

The staff's reactions are presented when the patients gather in large number. They are either willing to render kind service or become happy or become angry on seeing a large number of patients. Among the 300 staff members, about 58 percent of them render a kind service to the patients even though there is a crowd in the centres, 29.3 percent of them feel happy to render their good service. 10.4 percent of them no reaction i.e being normal to the patients. But only a few of them ( 2.3 percent) become angry.

Table 5: Gender and Patients Co - operation for Treatment - Chi -Square Test

\begin{tabular}{|c|c|c|c|}
\hline Patients Co-operation & Rate & $\begin{array}{c}\text { Degrees } \\
\text { of } \\
\text { Freedom }\end{array}$ & $\begin{array}{c}\text { Asymp. Sig. } \\
\text { (2-sided) } \\
\text { (P Value) }\end{array}$ \\
\hline Pearson Chi-Square & $16.221(\mathrm{a})$ & 12 & 0.658 \\
\hline Likelihood Ratio & 16.213 & 12 & 0.036 \\
\hline $\begin{array}{c}\text { Linear-by-Linear } \\
\text { Association }\end{array}$ & 0.035 & 1 & 0.764 \\
\hline N of Valid Cases & 300 & & \\
\hline Source: Computed Data & &
\end{tabular}

As far as the gender of the respondents and patients' co-operation for treatment are concerned, the ' $\mathrm{P}$ ' values are greater than 0.05 at five percent level of significance. So the null hypotheses are accepted and it is concluded that there is no significant difference between the gender of the respondents and patients co-operation for treatment.

\section{FINDINGS}

1. Majority $(73 \%)$ of the respondents are women.

2. Majority $(27.3 \%)$ age wise classification of the respondents are $31-40$ years.

3. Most (27\%) working in primary health centres designation is nurse.

4. Majority $(96 \%)$ of the populations are married.

5. Majority $(27.7 \%)$ of the populations are having four children in their family.

6. Majority (39.4\%) of the respondents were influenced by their fathers, uncles or other doctors who were role models in their childhood or they were inspired and encouraged by them to take up medical profession.

7. Majority (28\%) of the respondents have completed 3-6 years of service in PHCs.

8. Majority $(58 \%)$ of the respondents are rendering a kind service to the patients even though there is a crowd in the centres.

9. There is no significant difference between the men and women of the respondents and patients co-operation for treatment.

\section{CONCLUSION}

Strengthening the health facilities solely to physical infrastructure and putting the specified men on the duty doesn't guarantee an honest health to the community. It needs treatment to the set standards for each tangible and intangible deliverables. Patient satisfaction is Associate in nursing progressively vital issue, each in analysis and shaping health care. Additionally, patient evaluations will facilitate to teach medical employees concerning their achievements still as their failure, aiding them to be a lot of alert to their patients' wants. Therefore, patient satisfaction surveys ought to be meted out habitually all told side of health care to boost the standard of services. To boost the health care services of rural ladies folks and kids. To making awareness concerning the health care problems particularly maternal and kid health care through health education and totally different health care programmes. Health care centres make sure the betterment of health conditions of the people. The first health care services for a particular target population aim. To know however that population reacts to the combination of services provided and therefore the approach within which the health care system is union? Because the centres square measure within the management of state, no strict superintendence prevails, rather they serve with consciousness and build it a lot of voluntarily. Moreover, the agitated pace of life within the world. Nowadays is taking a good toll on people's body and mind. The villager's each body and minds feel a lot of comfortable only if they get treated well at centres wherever they are going for treatment. This shows the patients satisfaction that successively ensures the staff's satisfaction. Indeed, job satisfaction could be a parameter to assess the standard of health care services provided that successively confirms they are happy with their job. 


\section{REFERENCES}

1. Delfini and Reis, "Articulation between Public Health Services in Child-Care Mental Health Care", 2012.

2. Hamumappa "Rethinking Health Care Systems: Private Health Care Provision in India", Southern Economist, Volume: 37, No.12, October 15, 1998, pp: 1463-79.

3. Pant J.C., "Economic Participation of Rural Women in India, Women's status of women's autonomy", Southern Economist, Volume: 41, No.10, September 15, 2002, Page No.6.

4. Perez N.M., "Accessing Web - Based Health Related Information by College Students: An Exploratory Study", Californian Journal of Health Promotion, Volume: 9, Number: 4, 2006, pp: 64 - 74.

5. Rahman A. Mohammed, "Measuring and Explaining the Managerial Efficiency of Private Medical Clinics", 2006, pp: 84 - 152.

6. Sathyasundaram, "Infrastructure and Economic Development", Southern Economist, Volume: 36, No.1, May 1, 1990.

7. www.inflibnet.ac.in

\section{AUTHORS PROFILE}

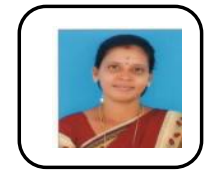

Dr. V. Sangeetha, working as an Assistant Professor of Commerce (Corporate Secretaryship) in Sri Sarada College for Women, Tirunelveli - 627011. She has completed her B.Com (2004), M.Com (2006), M.Phil (2010) and Ph.D (2014) in V.O.Chidambaram College, Thoothukudi 628008, Affiliated to Manonmaniam Sundaranar University, Tirunelveli - 627012. Certificate Course in Gandhian Thought (CGT) (2016) and Diploma Course in Gandhian Thought (DGT) (2017) in Madurai Kamaraj University, Madurai. She has produced 17 M.Phil Scholars and she is guiding 4 Ph.D Scholars under her guidance. She has successfully published in 2 books. She presented and published in 44 National and International Seminar. She participated in 8 State Level Workshop \& 3National Level Workshop. She also published papers in Scopus and UGC Care Journals.

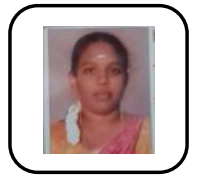

Miss K.Chandra, M.com. ,M.phil.,Ph.. D., Assistan professor of Commerce in A.P.C.Mahalaxmi College for Women, Thoothukudi. Her research interest includes Human Resource Management and Marketing

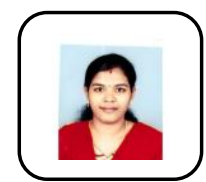

Mrs. R. Tiffany., M.Com., M.Phil., SET, is an Assistant Professor, Department of Commerce, Holy Cross Home Science College, Thoothukudi. She is pursuing her Doctor of Philosophy in Commerce in Manonmaniam Sundaranar University, Tirunelveli. Her research interests include Marketing and Banking.

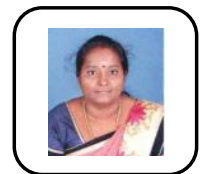

Mrs. S. Eswaralakshmi M.com., M.phil.,( part time research scholar in Sri Sarada college for women, tirunelveli) Assistant professor in M.D. T .Hindu college, tirunelveli. She interested in marketing and accountancy

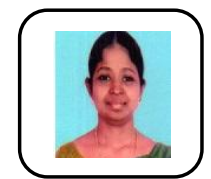

E.Shiney Janet, M.B.A.,M.Phil.,working as a principal in Tamil Institute of Science and Management, Vilathikulam. Residing at 3/183,Madurai road, guruvarpatti, vilathiklam, thoothukudi(dt)-628904. she is undergone the research under in the topic of Stress Management-"An Occupational Impedes Of Female Employees In Thoothukudi District". 